\title{
Temperature Dependence of the Heterogeneous Reaction of Carbonyl Sulfide on Magnesium Oxide
}

\author{
Yongchun Liu, Hong He,* and Qingxin Ma \\ State Key Laboratory of Environmental Chemistry and Ecotoxicology, Research Center for Eco-Environmental \\ Science, Chinese Academy of Sciences, Beijing 100085, China
}

Received: November 29, 2007; In Final Form: January 9, 2008

\begin{abstract}
The experimental determination of rate constants for atmospheric reactions and how these rate constants vary with temperature remain a crucially important part of atmosphere science. In this study, the temperature dependence of the heterogeneous reaction of carbonyl sulfide (COS) on magnesium oxide ( $\mathrm{MgO})$ has been investigated using a Knudsen cell reactor and a temperature-programmed reaction apparatus. We found that the adsorption and the heterogeneous reaction are sensitive to temperature. The initial uptake coefficients $\left(\gamma_{\mathrm{t}}(\mathrm{Ini})\right)$ of $\mathrm{COS}$ on $\mathrm{MgO}$ decrease from $1.07 \pm 0.71 \times 10^{-6}$ to $4.84 \pm 0.60 \times 10^{-7}$ with the increasing of temperature from 228 to $300 \mathrm{~K}$, and the steady state uptake coefficients $\left(\gamma_{\mathrm{t}}(\mathrm{SS})\right)$ increase from $5.31 \pm 0.06$ $\times 10^{-8}$ to $1.68 \pm 0.41 \times 10^{-7}$ with the increasing of temperature from 240 to $300 \mathrm{~K}$. The desorption rate constants $\left(k_{\text {des }}\right)$ were also found to increase slightly with the enhancement of temperature. The empirical formula between the uptake coefficients, desorption rate constants and temperature described in the form of Arrhenius expression were obtained. The activation energies for the heterogeneous reaction and desorption of $\mathrm{COS}$ on $\mathrm{MgO}$ were measured to be $11.02 \pm 0.34 \mathrm{~kJ} \cdot \mathrm{mol}^{-1}$ and $6.30 \pm 0.81 \mathrm{~kJ} \cdot \mathrm{mol}^{-1}$, respectively. The results demonstrate that the initial uptake of $\mathrm{COS}$ on $\mathrm{MgO}$ is mainly contributed by an adsorption process and the steady state uptake is due to a catalytic reaction. The environmental implication was also discussed.
\end{abstract}

\section{Introduction}

Carbonyl sulfide (COS) is the most abundant sulfur compound in the atmosphere, with a rather uniform mixing ratio of about 500 part per trillion by volume (pptv) in the troposphere. ${ }^{1-3}$ Its tropospheric lifetime is greater than 1 year, ${ }^{1,2}$ and the global atmospheric lifetime is from 2 to 8.9 years, calculated by different researchers. ${ }^{2,4}$ Chin et al. ${ }^{2}$ have reported that about $0.64 \mathrm{Tg} \cdot \mathrm{yr}^{-1}$ of COS is transported to the stratosphere from the troposphere, where its photolysis is the important source for the stratospheric sulfate layer. ${ }^{5}$ Therefore, the sinks of COS in the troposphere should affect the stratospheric sulfate source. Several atmospheric modeling studies have shown that atmospheric particles can potentially alter the chemical partitioning of gas-phase molecules, often acting as a sink for certain species. ${ }^{6-8}$ Recently, a few studies have reported the heterogeneous reactions of $\mathrm{COS}$ on atmospheric particles, and mineral oxides including $\mathrm{Al}_{2} \mathrm{O}_{3}, \mathrm{SiO}_{2}, \mathrm{Fe}_{2} \mathrm{O}_{3}, \mathrm{CaO}, \mathrm{MgO}$ and $\mathrm{MnO}_{2}$ as well. ${ }^{9-14}$ Hydrogen thiocarbonate $\left(\mathrm{HSCO}_{2}{ }^{-}\right)$was found as a key intermediate. Gaseous carbon dioxide $\left(\mathrm{CO}_{2}\right)$ and surface sulfate $\left(\mathrm{SO}_{4}{ }^{2-}\right)$ were found to be the gaseous and surface products, ${ }^{11-14}$ respectively. Surface sulfite ${ }^{11,12}$ and elemental sulfur ${ }^{9,10}$ were also observed as surface sulfur species. Additionally, hydrogen sulfide $\left(\mathrm{H}_{2} \mathrm{~S}\right)$ was detected as one of the gaseous products for the heterogeneous reaction of $\mathrm{COS}$ on $\mathrm{MgO} .{ }^{13}$ The previous work demonstrates that heterogeneous reaction of COS on mineral dust is a potential sink for COS in the troposphere. However, little attention was given to the reaction kinetic of COS on mineral oxides.

On the other hand, the temperature in the Earth's atmosphere varies with latitude, longitude, and altitude above the earth's

* Corresponding author. Phone: +86-10-62849123; fax: +86-1062923563; e-mail: honghe@rcees.ac.cn. surface, as well as the season and the time of day. For example, the tropospheric temperature for latitude $40^{\circ} \mathrm{N}$ during June decreases from room temperature (r.t.) to $220 \mathrm{~K}$ with the increase of altitude. ${ }^{15}$ In reality, the temperature at the tropopause can reach values much lower than $220 \mathrm{~K}$, down to 180 $\mathrm{K}$ above the Antarctic in winter. ${ }^{15,16}$ Therefore, the experimental determination of rate constants for important atmospheric reactions and how these rate constants vary with temperature remain a crucially important part of atmosphere science. ${ }^{15}$ In the past decades, many researchers have investigated the heterogeneous reactions of $\mathrm{N}_{2} \mathrm{O}_{5}, \mathrm{ClONO}_{2}, \mathrm{NO}_{2}, \mathrm{HNO}_{3}, \mathrm{SO}_{2}$, $\mathrm{O}_{3}$, and so forth, on ice, sea salt, soot, and mineral oxides in laboratory, ${ }^{17-20}$ while most of the work was performed at one temperature point, generally, at room temperature. Additionally, the mineral dust particle represents one of the largest natural mass fractions of the global aerosol with an annual emission of about $1000-3000 \mathrm{Tg} .{ }^{21}$ Even at altitudes of $10-12 \mathrm{~km}$, mineral ions including $\mathrm{Mg}^{2+}, \mathrm{Ca}^{2+}, \mathrm{Na}^{+}, \mathrm{K}^{+}$, and so forth were also detected in the aerosol samples. It indicates that mineral dust particles are also transported into the upper troposphere by convection. $^{22,23}$ Therefore, it is significant to investigate the dependence of rate constants on the temperature for the heterogeneous reactions of trace gases on mineral dust particles.

$\mathrm{MgO}$ is one of the typical components of mineral dust, whose content is about $6.1 \mathrm{wt} \%$ of the inorganic components in the Beijing area. ${ }^{11,24}$ On the other hand, the reaction mechanism of $\mathrm{COS}$ on $\mathrm{MgO}$ indicates that the heterogeneous reaction of $\mathrm{COS}$ on $\mathrm{MgO}$ may have important effect on the global sink of COS in the troposphere. ${ }^{13}$ Therefore, in this work, we investigated the temperature dependence in the range of 300-228 K for the heterogeneous reaction of COS on $\mathrm{MgO}$. The uptake coefficients of adsorption and heterogeneous reaction, and the desorption rate constants were measured with a Knudsen cell-mass 
spectrometer (KCMS). The energy change in the reaction coordinate was also discussed. The results are helpful for further understanding the heterogeneous reaction of COS on mineral dust particles as well as the spatial distribution of activity for this reaction in the troposphere. In addition, the uptake coefficients at different temperatures will supply the basic data for model studies.

\section{Experimental Details}

2.1. Materials. The $\mathrm{MgO}$ sample (A.R.) used in this experiment was supplied by Haizhong Chemical Plant in Tianjin. The impurities in the $\mathrm{MgO}$ sample include $\mathrm{Cl}(0.01 \%), \mathrm{SO}_{4}{ }^{2-}$ $(0.02 \%), \mathrm{PO}_{4}{ }^{3-}(0.003 \%), \mathrm{CO}_{3}{ }^{2-}(1.5 \%), \mathrm{Na}(0.05 \%), \mathrm{K}$ $(0.005 \%), \mathrm{Ca}(0.02 \%), \mathrm{Fe}(0.005 \%), \mathrm{Cu}(0.001 \%), \mathrm{Zn}(0.005 \%)$, As $(0.0001 \%), \mathrm{Ba}$, and $\mathrm{Sr}(0.005 \%)$. The following chemicals were used without further purification: carbonyl sulfide (COS, $2 \%, \mathrm{COS} / \mathrm{N}_{2}$, Scott Specialty Gases, Inc.); $\mathrm{N}_{2}$ and $\mathrm{O}_{2}(99.99 \%$ purity, Beijing AP BEIFEN Gases, Inc.).

2.2. Characterization of Sample. Nitrogen BrunauerEmmett-Teller (BET) physisorption measurement was performed using a Micromeritics ASAP 2000 automatic equipment. It was shown that the $\mathrm{MgO}$ sample has a total surface area of $14.6 \mathrm{~m}^{2} \cdot \mathrm{g}^{-1}$. The X-ray powder diffraction pattern was collected from 10 to $90^{\circ} 2 \theta$ on a D/max-RB automatic powder X-ray diffractometer using $\mathrm{Cu} \mathrm{K} \alpha$ irradiation. The $\mathrm{MgO}$ sample was identified to be periclase with the three main $2 \theta$ peaks at $42.918^{\circ}, 62.300^{\circ}$ and $78.622^{\circ}$.

2.3. Experimental Methods. KCMS Experiments. A Knudsen cell reactor coupled to a quadrupole mass spectrometer (QMS, Hiden, HAL 3F PIC) was used to determine the uptake coefficients of $\mathrm{COS}$ on $\mathrm{MgO}$. The mass spectrometer was housed in a vacuum chamber equipped with a $300 \mathrm{~L} \cdot \mathrm{s}^{-1}$ turbomolecular pump (Pfeiffer) and an ion gauge (BOC Edward). The vacuum chamber between the QMS and the Knudsen cell reactor was pumped by a $60 \mathrm{~L} \cdot \mathrm{s}^{-1}$ turbomolecular pump for differential pumping of the mass spectrometer and an ion gauge (both from BOC Edward). The Knudsen cell reactor consisted of a stainless steel chamber with a gas inlet controlled by a leak valve, an escape aperture whose area can be adjusted with an adjustable iris in the range of $0-300 \mathrm{~mm}^{2}$, and a sample holder attached to the top ceiling of a circulating fluid bath. The effective area of escape aperture was measured in each independent experiment according to the attenuation of the $\mathrm{N}_{2}$ signal from one steady state to another. ${ }^{25}$ It was about $0.40 \mathrm{~mm}^{2}$ in our experiments. The geometric area of the sample holder $\left(A_{\mathrm{s}}\right)$ was $5.26 \mathrm{~cm}^{2}$. A blank flange, serving as sample cover, attached to a linear translator made it possible to either isolate or expose the sample to reactant gas. No corrections were needed because the volume change upon opening the sample cover was less than $0.52 \mathrm{~cm}^{3}$, and the total volume of reactor chamber was $94.0 \mathrm{~cm}^{3}$. The seal between the cover and sample holder was made with a Teflon O-ring. All exposed interior surfaces including the surface of the sample holder were coated with Teflon to provide a chemically inert surface. Blank experiment revealed that there was no uptake due to the sample holder and the sample cover. The temperature of the sample holder, which was measured with an embedded Pt resistance thermometer, could be controlled from 220 to $373 \mathrm{~K}$ within $\pm 0.10 \mathrm{~K}$ by using a super thermostat and a cryofluid pump (DFY 5/80, Henan Yuhua laboratory instrument factory).

The 40.0-120.0 mg of MgO samples were dispersed evenly on a sample holder with alcohol and then dried at $393 \mathrm{~K}$ for 2 $h$. The pretreated samples and reactor chamber were evacuated at $323 \mathrm{~K}$ for $6 \mathrm{~h}$ to reach a base pressure of approximately 5.0

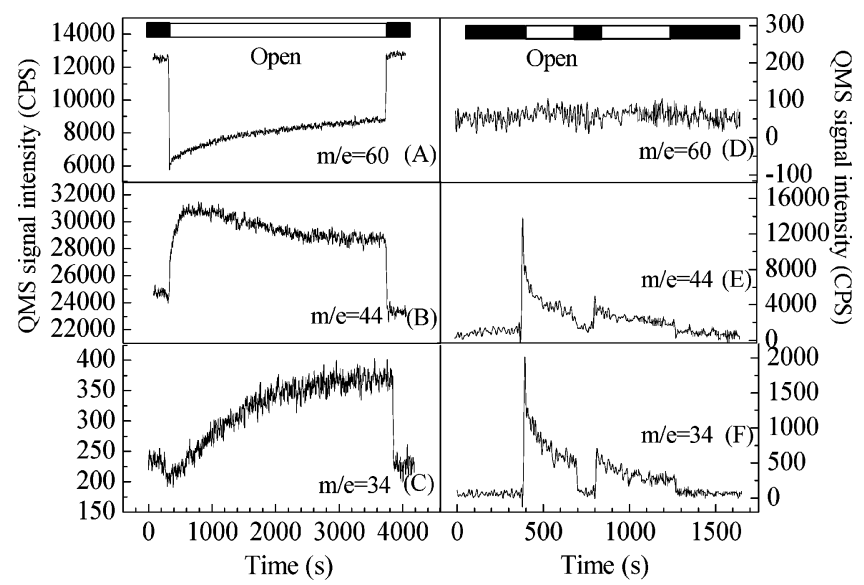

Figure 1. The uptake of COS and desorption of surface products on $100.0 \mathrm{mg} \mathrm{MgO}$ at $300 \mathrm{~K}$. The average COS partial pressure in the Knudsen cell reactor was $5.3 \pm 0.3 \times 10^{-6}$ Torr. (A), (B), (C) are the temporal concentration profiles for $\operatorname{COS}(m / e=60), \mathrm{CO}_{2}(\mathrm{~m} / e=44)$, and $\mathrm{H}_{2} \mathrm{~S}(m / e=34)$ in the uptake experiment; (D), (E), (F) are these in the in situ desorption experiment.

$\times 10^{-7}$ Torr. After the system was cooled to a given temperature $(228-300 \mathrm{~K})$, the sample cover was closed. $1.51 \%$ COS balanced with simulated air $\left(21 \% \quad \mathrm{O}_{2}\right.$ and $\left.79 \% \quad \mathrm{~N}_{2}\right)$ was introduced into the reactor chamber through a leak valve. The pressure in the reactor was measured using an absolute pressure transducer (BOC Edward). Prior to the experiments, the reactor chamber was passivated with $\mathrm{COS}$ in air for $150 \mathrm{~min}$ until a steady state of QMS signal was established while the oxide samples were isolated from the gas by the sample cover. Uptake measurements on all samples were obtained with an average COS partial pressure of $5.3 \pm 0.3 \times 10^{-6}$ Torr, which was equivalent to $1.7 \pm 0.2 \times 10^{11}$ molecules $\mathrm{cm}^{-3}$ or $7.0 \pm 0.3$ $\mathrm{ppb}$ in the atmosphere. The uptake coefficients and desorption rate constants were calculated based on the KCMS data.

$T P R$ Experiment. The instantaneous experiment for the heterogeneous reaction of $\mathrm{COS}$ on $\mathrm{MgO}$ was performed with a temperature-programmed reaction (TPR) apparatus. It consists of a temperature-programmed tube oven and a QMS (Hiden HPR20). $\mathrm{MgO}$ samples (0.5 g) were pretreated in simulated air at $573 \mathrm{~K}$ for $1 \mathrm{~h}$. After the sample was cooled to $298 \mathrm{~K}$, it was exposed to $0.1 \%$ COS balanced with simulated air with a total flow rate of $100 \mathrm{~mL} \cdot \mathrm{min}^{-1}$. The temperature was increased from 298 to $430 \mathrm{~K}$ at $20 \mathrm{~K} \cdot \mathrm{min}^{-1}$. The mass channels including $\mathrm{m} / \mathrm{e}$ $=60(\mathrm{COS}), 44\left(\mathrm{CO}_{2}\right), 34\left(\mathrm{H}_{2} \mathrm{~S}\right)$, and $64\left(\mathrm{SO}_{2}\right)$ were monitored with the QMS online. The blank experiment with a quartz tube was also carried out under the same conditions.

\section{Results and Discussion}

3.1. Reaction Pathway and Kinetics for the Heterogeneous Reaction of COS on MgO. Figure 1 shows a typical KCMS profile for the uptake of COS on $100.0 \mathrm{mg}$ of $\mathrm{MgO}$ at $300 \mathrm{~K}$. The average COS partial pressure in the Knudsen cell reactor was $5.3 \pm 0.3 \times 10^{-6}$ Torr, which is equivalent to $1.7 \pm 0.2 \times$ $10^{11}$ molecules $\mathrm{cm}^{-3}$ or $7.0 \pm 0.3 \mathrm{ppb}$ in the atmosphere. It can be seen that the mass signal intensity of $\operatorname{COS}(m / e=60)$ decreased dramatically after opening the sample cover (Figure 1A). The uptake of COS was accompanied by the production of $\mathrm{CO}_{2}(m / e=44)$ and $\mathrm{H}_{2} \mathrm{~S}(m / e=34)$ on $\mathrm{MgO}$ (Figure $\left.1 \mathrm{~B}, \mathrm{C}\right)$. In our previous work, ${ }^{13}$ we also observed the formation of gaseous $\mathrm{CO}_{2}$ at 2341 and $2361 \mathrm{~cm}^{-1}$, and surface $\mathrm{HS}$ at 2578 $\mathrm{cm}^{-1}$ using in situ DRIFTS to study the heterogeneous reaction of $\mathrm{COS}$ on $\mathrm{MgO}$ at $303 \mathrm{~K}$. The KCMS results support the in situ DRIFTS experiment results very well. In Figure 1A, the 
initial uptake of COS was followed by a quick saturation process, leading to an apparent steady-state uptake on the time scale of this experiment. The quick saturation can be ascribed to the adsorption process. It is very interesting that the maximal yields of $\mathrm{CO}_{2}$ and $\mathrm{H}_{2} \mathrm{~S}$ lagged behind the maximal consumption of COS. This phenomenon is related to the adsorption of $\mathrm{CO}_{2}$ and $\mathrm{H}_{2} \mathrm{~S}$ on the basic site of $\mathrm{MgO}$. In Figure 1, the maximal yield of $\mathrm{H}_{2} \mathrm{~S}$ was also later than that of $\mathrm{CO}_{2}$, which could be explained by the reasons that the acidity of $\mathrm{H}_{2} \mathrm{~S}$ is stronger than that of $\mathrm{CO}_{2}$, and thus $\mathrm{H}_{2} \mathrm{~S}$ is more readily to be adsorbed on the basic site of $\mathrm{MgO}$.

In the end of the uptake process, the in situ desorption of surface species was carried out. After the sample was isolated from the feed gas by the sample cover, the feed gases were ceased from being introduced into the reactor, and then the escape aperture area was increased to $300 \mathrm{~mm}^{2}$ from $0.40 \mathrm{~mm}^{2}$ using a variable iris to increase the flow rate of gases from the Knudsen cell reactor into the QMS detector. When the pressure in the Knudsen cell decreased to $5.0 \times 10^{-7}$ Torr, the sample cover was opened, and the desorbed species were monitored online with the QMS. As shown in Figure 1D-F, as the sample cover opened, desorption of $\mathrm{CO}_{2}$ and $\mathrm{H}_{2} \mathrm{~S}$ was clearly observed. When the sample cover was closed, the QMS signal for $\mathrm{CO}_{2}$ and $\mathrm{H}_{2} \mathrm{~S}$ decreased to their baselines. In Figure 1D, no desorption of COS was detected. Using in situ DRIFTS, we identified hydrogen thiocarbonate $\left(\mathrm{HSCO}_{2}{ }^{-}\right)$as the key intermediate, ${ }^{13}$ which is formed by the reaction of COS with surface hydroxyl. Therefore, we here appoint $\mathrm{HSCO}_{2}{ }^{-}$as one of the adsorbed species for $\mathrm{COS}$ adsorbed on $\mathrm{MgO}$. The above results suggest that $\mathrm{COS}$ can easily react with $\mathrm{OH}^{-}$on $\mathrm{MgO}$, and then quickly translate to $\mathrm{HSCO}_{2}{ }^{-}$, and the adsorbed $\mathrm{HSCO}_{2}{ }^{-}$can hardly desorb from the surface. The desorption of $\mathrm{CO}_{2}$ and $\mathrm{H}_{2} \mathrm{~S}$ or the decomposition of the intermediate $\left(\mathrm{HSCO}_{2}{ }^{-}\right)$should be a ratedetermining step (RDS) for the heterogeneous reaction of COS on $\mathrm{MgO}$. These results also suggest that the reverse reaction for the heterogeneous reaction of $\mathrm{COS}$ on $\mathrm{MgO}$ is very slow. However, it should be noted that the concentration of COS in the Knudsen cell reactor is very low. According to the signalto-noise ratio (SNR) of QMS signal, the low limit of the QMS is about $2 \times 10^{14}$ molecules $(3 \sigma)$ for COS. The quantity of desorbed COS molecule may be lower than the sensitivity of QMS. Although the desorption of COS was not observed directly, according to the reversible principle, the reverse reaction must occur, but it is very slow. On the basis of our previous work $^{13}$ and KCMS results, the reaction can be described as R1.

$$
\operatorname{COS}(\mathrm{g}) \underset{k_{\mathrm{d}}}{\stackrel{k_{\mathrm{a}}}{\rightleftarrows}} \mathrm{COS}(\mathrm{ads}) \stackrel{k_{\mathrm{h}}}{\rightleftharpoons} \mathrm{CO}_{2}(\mathrm{~g})+\mathrm{H}_{2} \mathrm{~S}(\mathrm{~g})
$$

3.2. The Effect of Temperature on the Heterogeneous Reaction of COS on MgO. The results from KCMS and in situ DRIFTS ${ }^{13}$ demonstrate that the heterogeneous reaction of $\mathrm{COS}$ on $\mathrm{MgO}$ belongs to catalytic reaction. Therefore, temperature should have an important influence on the reaction. It is also significant to determine the step rate constants in R1. Figure 2 shows a temporal concentration profile for the TPR experiment in the range of $298-430 \mathrm{~K}$. Because the reactor for TPR could not be cooled to low temperature (below $298 \mathrm{~K}$ ), the experiment above $298 \mathrm{~K}$ was performed. It can be seen in Figure 2B when $0.1 \%$ COS balanced with simulated air passed through the quartz reactor (the control experiment), the concentration of $\operatorname{COS}(\mathrm{m} / \mathrm{e}$ $=60), \mathrm{CO}_{2}(m / e=44)$, and $\mathrm{H}_{2} \mathrm{~S}(m / e=34)$ did not change with the increasing of temperature. It suggests that the quartz reactor has no catalytic activity for the reaction (R1) in the range
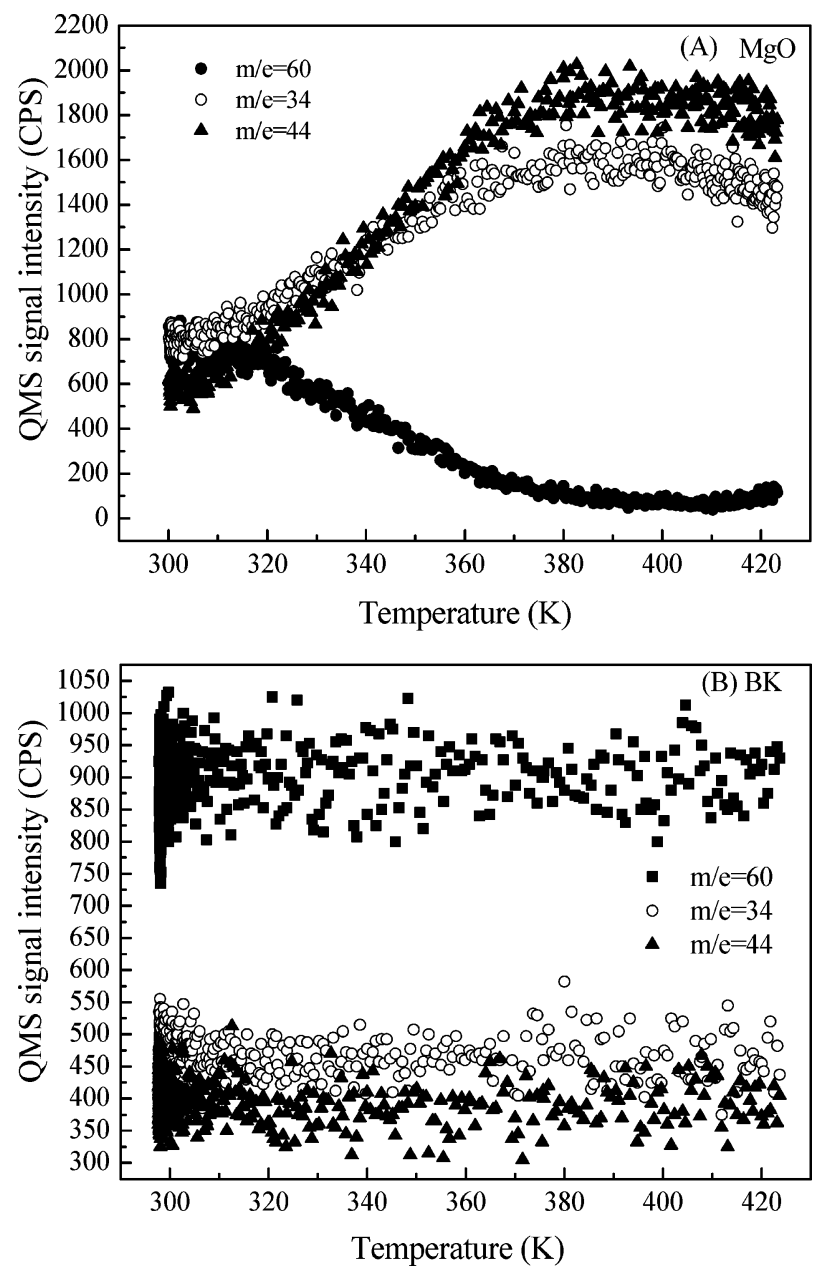

Figure 2. The temporal concentration profile for temperatureprogrammed reaction of COS on $\mathrm{MgO}$ in the range of $298-430 \mathrm{~K}$ at $20 \mathrm{~K} \cdot \mathrm{min}^{-1}$. (A) $0.5 \mathrm{~g} \mathrm{MgO}$ was exposed to $0.1 \% \mathrm{COS}$ balanced with simulated air, and (B) is the control experiment.

of experimental temperature. It also indicates that gaseous COS does not decompose into other products under the experiment conditions. However, the case is not true when the reactant gases passing through $0.5 \mathrm{~g} \mathrm{MgO}$ sample. As shown in Figure 2A, the concentration of COS decreased dramatically with the temperature increasing, which was accompanied by the increasing of the concentration of $\mathrm{CO}_{2}$ and $\mathrm{H}_{2} \mathrm{~S}$. When the temperature increased to $380 \mathrm{~K}$, the concentration of COS decreased to the lowest level, which corresponded to the highest concentration of $\mathrm{CO}_{2}$ and $\mathrm{H}_{2} \mathrm{~S}$. Because the background noise of the QMS for COS is about 200 CPS; therefore, the conversion for COS at $380 \mathrm{~K}$ should be $100 \%$. According to reaction R1, the amount of produced $\mathrm{H}_{2} \mathrm{~S}$ ought to be the same as that of $\mathrm{CO}_{2}$. Therefore, the increase rate (slope) for $\mathrm{H}_{2} \mathrm{~S}$ should be the same as that of $\mathrm{CO}_{2}$ in Figure 2A. However, the increase rate for $\mathrm{H}_{2} \mathrm{~S}$ is slower than that of $\mathrm{CO}_{2}$ slightly. As discussed in section 3.1, the adsorption ability of $\mathrm{H}_{2} \mathrm{~S}$ on $\mathrm{MgO}$ is stronger than that of $\mathrm{CO}_{2}$. On the other hand, $\mathrm{H}_{2} \mathrm{~S}$ can be oxidized to other surface sulfurcontaining species, including element sulfur ( $\mathrm{S}$ ), sulfur dioxides $\left(\mathrm{SO}_{2}\right)$, sulfite $\left(\mathrm{SO}_{3}{ }^{2-}\right)$, bisulfite $\left(\mathrm{HSO}_{3}{ }^{-}\right)$, and sulfate $\left(\mathrm{SO}_{4}{ }^{2-}\right)^{9-14}$ under the reaction conditions. Therefore, TPR results are in good agreement with the KCMS results. In Figure 2B, the signal intensity of $\mathrm{COS}$ is much higher than that of $\mathrm{CO}_{2}$ and $\mathrm{H}_{2} \mathrm{~S}$ at $298 \mathrm{~K}$, while it is not this way in Figure 2A. This difference is due to the production of $\mathrm{CO}_{2}$ and $\mathrm{H}_{2} \mathrm{~S}$ by reaction $\mathrm{R} 1$ on $\mathrm{MgO}$ at $298 \mathrm{~K}$ (Figure 2A). The TPR results indicate that the heterogeneous reaction of $\mathrm{COS}$ on $\mathrm{MgO}$ is sensitive to tem- 


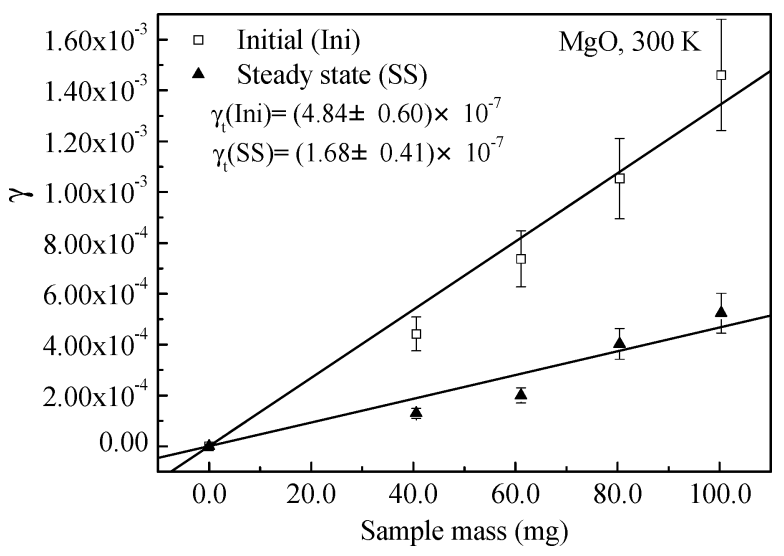

Figure 3. The linear mass dependence for the uptake coefficient of $\mathrm{COS}$ on $\mathrm{MgO}$ at $300 \mathrm{~K}$.

perature. Consequently, the kinetic and the temperature dependence of heterogeneous reaction for $\mathrm{COS}$ on $\mathrm{MgO}$ will be discussed in the following section.

In atmospheric chemistry, uptake coefficient is the most commonly used kinetic parameter. The uptake coefficient $(\gamma)$ is defined by eq 1 :

$$
\gamma=\frac{-\frac{\mathrm{d} n}{\mathrm{~d} t}}{\omega}
$$

where $-(\mathrm{d} n / \mathrm{d} t)$ is the number of molecules lost from the gasphase per second due to the collision between gas molecules and solid surface (molecules $\bullet \mathrm{s}^{-1}$ ), and $\omega$ is the total number of gas-surface collisions per second, namely, collision frequency. ${ }^{26}$ For steady-state uptake, the uptake coefficient can be calculated using the Knudsen cell equation: ${ }^{26-29}$

$$
\gamma=\frac{A_{\mathrm{h}}}{A_{\mathrm{s}}} \frac{\left(I_{0}-I\right)}{I}
$$

where $A_{\mathrm{h}}$ is the effective area of the escape aperture $\left(\mathrm{m}^{2}\right), A_{\mathrm{s}}$ is the geometric area of the sample holder $\left(\mathrm{m}^{2}\right) ; I_{0}$ and $I$ are the mass spectral intensities with the sample holder closed and open, respectively. As for the multilayer powder sample, the linear mass dependent (LMD) region of the observed uptake coefficient has been reported by different groups in various reaction systems, and has been ascribed to the diffusion of reactant molecules into the underlying layers of multilayer powder samples. ${ }^{29-33}$ Therefore, the true uptake coefficients, $\gamma_{t}$, can be calculated from

$$
\gamma_{\mathrm{t}}=\operatorname{slope} \cdot\left(\frac{A_{\mathrm{s}}}{S_{\mathrm{BET}}}\right)
$$

where "slope" is the slope of the plot of $\gamma$ versus sample mass in the linear regime $\left(\mathrm{kg}^{-1}\right), A_{\mathrm{s}}$ is the geometric area $\left(\mathrm{m}^{2}\right)$ of the sample holder, and $S_{\mathrm{BET}}$ is the specific surface area of the particle sample $\left(\mathrm{m}^{2} \cdot \mathrm{kg}^{-1}\right) .{ }^{34}$

As shown in Figure 3, there was a strong linear dependence of uptake coefficients at the initial time $\gamma$ (Ini) and at steady state $\gamma(\mathrm{SS})$ versus sample mass. The correlation coefficients were 0.990 and 0.966 , respectively. When the sample mass increased to $120 \mathrm{mg}$, the uptake coefficients reached a constant value. According to eq $3, \gamma_{\mathrm{t}}(\mathrm{Ini})$ and $\gamma_{\mathrm{t}}(\mathrm{SS})$ at $300 \mathrm{~K}$ were calculated to be $4.84 \pm 0.60 \times 10^{-7}$ and $1.68 \pm 0.41 \times 10^{-7}$, respectively. The error bar in Figure 3 was $15.0 \%$ obtained from

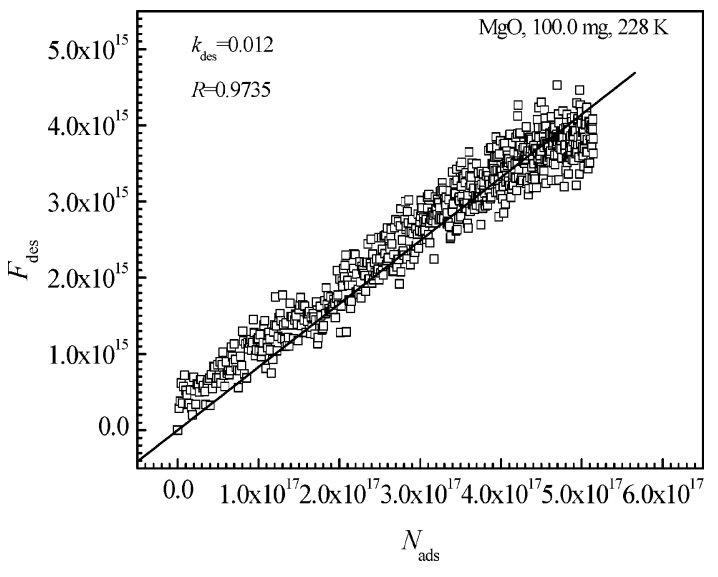

Figure 4. The desorption rate verse adsorption quantity.

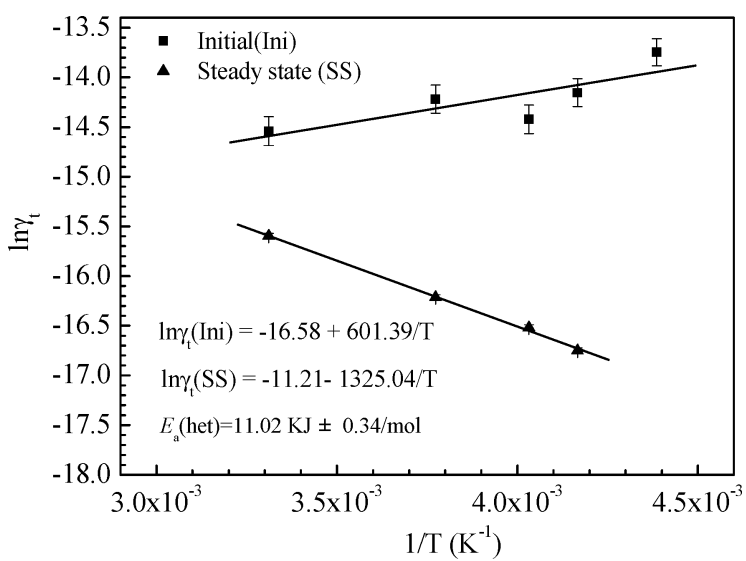

Figure 5. The relationship between the uptake coefficients of COS on $\mathrm{MgO}$ and temperature.

the repetitive experiments. The true uptake coefficients for COS on $\mathrm{MgO}$ were also measured at 228, 240, 248, and $265 \mathrm{~K}$.

When the temperature decreased to $228 \mathrm{~K}$, only adsorption of $\mathrm{COS}$ on $\mathrm{MgO}$ was observed. The saturated adsorptive capacity for $\mathrm{COS}$ on $\mathrm{MgO}$ was measured to be $7.1 \pm 1.2 \times$ $10^{18}$ molecules $\cdot \mathrm{g}^{-1}$. Taking into account the BET surface area of $\mathrm{MgO}$ of $1.46 \times 10^{5} \mathrm{~cm}^{2} \cdot \mathrm{g}^{-1}$ and the size of an adsorbed COS molecule around $10^{-15} \mathrm{~cm}^{2}$, the COS saturated adsorption on $\mathrm{MgO}$ is close to one monolayer at $228 \mathrm{~K}$. At other temperatures, the concentration profiles for the uptake of COS were similar to that at $300 \mathrm{~K} . \mathrm{H}_{2} \mathrm{~S}$ and $\mathrm{CO}_{2}$ were also found as the gaseous products. Therefore, the uptake of COS is contributed by both adsorption and heterogeneous reaction. The values of $\gamma_{\mathrm{t}}(\mathrm{Ini})$ and $\gamma_{\mathrm{t}}(\mathrm{SS})$ are given in Table 1. The rate constants for adsorption, desorption, and heterogeneous reaction (catalytic reaction) of COS on $\mathrm{MgO}$ are also shown in Table 1 and will be discussed later. As can be seen in Table 1, the values of $\gamma_{t}$ (Ini) decreased with the increasing of temperature, while it was reversed for $\gamma_{\mathrm{t}}(\mathrm{SS})$. It means that the uptake at the initial stage is an exothermic process, and the uptake at the steadystate needs an active energy. Therefore, we can conclude that the initial uptake of $\mathrm{COS}$ on $\mathrm{MgO}$ is mainly due to an adsorption process, while, at the steady state, the uptake is mainly contributed by catalytic reaction.

In our previous work, we have found that the heterogeneous reaction of $\mathrm{COS}$ on $\mathrm{MgO}$ is a first-order reaction. ${ }^{14}$ Therefore, the reaction rate constant can be derived from eq 4 :

$$
-\frac{\mathrm{d} c}{\mathrm{~d} t}=k \cdot c=\frac{\gamma \cdot \omega}{V}
$$


TABLE 1: The Kinetic Parameters for the Heterogeneous Reaction of COS on MgO

$\begin{array}{llllll}T(\mathrm{~K}) & 228 & 240 & 248 & 265 & 300 \\ \gamma_{\mathrm{t}} \text { (Ini) } & 1.07 \pm 0.71 \times 10^{-6} & 7.13 \pm 0.19 \times 10^{-7} & 5.46 \pm 0.33 \times 10^{-7} & 6.68 \pm 0.12 \times 10^{-7} & 4.84 \pm 0.60 \times 10^{-7} \\ \gamma_{\mathrm{t}}(\mathrm{SS}) & & 5.31 \pm 0.06 \times 10^{-8} & 6.69 \pm 0.46 \times 10^{-8} & 9.09 \pm 0.12 \times 10^{-8} & 1.68 \pm 0.41 \times 10^{-7} \\ k_{\mathrm{ads}}\left(\mathrm{s}^{-1}\right) & 1.19 \pm 0.79 & 8.11 \pm 0.22 \times 10^{-1} & 6.31 \pm 0.38 \times 10^{-1} & 7.98 \pm 0.14 \times 10^{-1} & 6.15 \pm 0.76 \times 10^{-1} \\ k_{\text {des }}\left(\mathrm{s}^{-1}\right) & 1.21 \pm 0.01 \times 10^{-2} & 1.39 \pm 0.09 \times 10^{-2} & 1.59 \pm 0.03 \times 10^{-2} & & \\ k_{\mathrm{h}}\left(\mathrm{s}^{-1}\right) & & 6.04 \pm 0.07 \times 10^{-2} & 7.73 \pm 0.53 \times 10^{-2} & 1.09 \pm 0.01 \times 10^{-1} & 2.14 \pm 0.52 \times 10^{-1}\end{array}$

Here, $c$ is the molecule concentration of COS in the Knudsen cell reactor $\left(\mathrm{mol} \cdot \mathrm{m}^{-3}\right) ; V$ is the volume of the Knudsen cell reactor $\left(\mathrm{m}^{3}\right) ; k$ is the first-order reaction rate constant $\left(\mathrm{s}^{-1}\right)$. When the mean free path of molecules in the Knudsen cell is greater than the cell dimensions, the collision frequency between the gas-phase molecules and the reactive surface can be calculated by eq $5:{ }^{34}$

$$
\omega=\frac{\bar{v} \cdot c \cdot A_{\mathrm{s}}}{4}
$$

where $\bar{v}$ is the average molecular speed $\left(\mathrm{m} \cdot \mathrm{s}^{-1}\right)$. Therefore, the rate constant can be calculated by eq $6: 35$

$$
k=\frac{\bar{v} \cdot \gamma \cdot A_{\mathrm{s}}}{4 V}
$$

When the true uptake coefficient $\left(\gamma_{\mathrm{t}}\right)$ is used in eq 6 , the geometric area of the sample holder $\left(A_{\mathrm{S}}\right)$ should be replaced with the effective collision area $\left(A_{\mathrm{BET}}\right)$. The rate constants for the heterogeneous reaction $\left(k_{\mathrm{h}}\right)$ in Table 1 were calculated on the basis of the steady state uptake coefficients. At the moment the sample was exposed to the reactant gas, the lost of gaseous molecules due to the heterogeneous reaction may be neglected when compared with adsorption. Therefore, the adsorption rate constants can be calculated based on the initial uptake coefficients according to eq $6 .{ }^{22,36}$

As for the desorption rate constants, Seisel et al. ${ }^{22,36}$ have proposed a calculation method based on the flux balance equation according to the uptake profile using KCMS. That is,

$$
\begin{gathered}
F_{\mathrm{des}}(t)=k_{\mathrm{des}} N_{\mathrm{ads}}(t) \\
F_{\mathrm{des}}(t)=F(t)\left(1+\frac{k_{\mathrm{ini}}}{k_{\mathrm{esc}}}\right)-F_{0}
\end{gathered}
$$

where $F_{\text {des }}(t)$ is the flow out of the reactor at time $t$ (molecules $\left.\bullet \mathrm{s}^{-1}\right) ; k_{\mathrm{des}}$ is the desorption rate constant $\left(\mathrm{s}^{-1}\right) ; N_{\mathrm{ads}^{-}}$ $(t)$ is the number of adsorbed molecule on the surface; $F_{0}$ is the flow into the reactor (molecules ${ }^{-1}{ }^{-1}$; $k_{\text {ini }}$ is the initial rate constant and equals $k_{\text {ads }}\left(\mathrm{s}^{-1}\right) ; k_{\text {esc }}$ is the escape rate constant of the Knudsen cell $\left(\mathrm{s}^{-1}\right)$, and $k_{\mathrm{esc}}=\omega \cdot A_{h}$. The number of molecules adsorbed on the surface at time $t, N_{\text {ads }}(t)$, can be determined by integrating the MS signal between $t=0$ and the desired time $t$. If the heterogeneous process includes a catalytic reaction, eq 8 should be corrected with eq 9 :

$$
F_{\text {des }}(t)=F(t)\left(1+\frac{k_{\text {ini }}}{k_{\text {esc }}}\right)+k_{\mathrm{h}} N_{\text {ads }}(t)-F_{0}
$$

However, in the most cases for the heterogeneous reaction of $\mathrm{COS}$ on $\mathrm{MgO}$ at low temperature, the value of $F(t)\left(1+\left(k_{\mathrm{ini}} /\right.\right.$ $\left.k_{\text {esc }}\right)$ ) is much greater than that of $k_{\mathrm{h}} N_{\text {ads }}$. Therefore, the desorption rate constants given in Table 1 were approximately calculated from eq 8 . The typical relationship between $F_{\text {des }}(t)$ and $N_{\text {ads }}(t)$ is shown in Figure 4. And the desorption rate constants at 228,240 , and $248 \mathrm{~K}$ were given in Table 1 . The sample mass in these experiments was fixed to be $100.0 \mathrm{mg}$, which is in the linear range between the observed uptake coefficient and the sample mass. When the temperature was higher than $248 \mathrm{~K}$, the effect of the heterogeneous reaction became prominent and the correlation between $F_{\text {des }}(t)$ and $N_{\mathrm{ads}^{-}}$ $(t)$ was very bad. Therefore, the desorption rate constants at 265 and $300 \mathrm{~K}$ were not given in Table 1. As shown in Table 1 , the desorption rate constants increased with the increasing of temperature, which means the desorption process is also an endothermic process. From 228 to $248 \mathrm{~K}, k_{\mathrm{ads}}, k_{\mathrm{des}}$, and $k_{\mathrm{h}}$ are in the order of $k_{\text {ads }}>k_{\mathrm{h}}>k_{\text {des. }}$. The desorption rate constants are lower than both the adsorption rate constants and the heterogeneous reaction rate constants, which means that the desorption process is a slow step. It well supports the above assumption that the reverse reaction or desorption of COS is very slow. On the other hand, for the positive reaction, the heterogeneous reaction rate constants are lower than the adsorption rate constants, even at $300 \mathrm{~K}$. The fast adsorption process suggests that the adsorption should be a relatively important heterogeneous process for COS on the surface of mineral dust particles in the atmosphere, especially, at low temperature. However, when compared with the heterogeneous reaction (catalytic reaction), the total amount of COS adsorbed on the mineral dust particle should be a limited quantity on a long time scale.

Figures 5 and 6 show the linear regression of $\gamma_{\mathrm{t}}(\mathrm{Ini}), \gamma_{\mathrm{t}}(\mathrm{SS})$, and $k_{\text {des }}$ with the reciprocal value of temperature $(1 / T)$. The correlation coefficients are $0.813,0.999$, and 0.992 , respectively. Therefore, $\gamma_{\mathrm{t}}(\mathrm{Ini}), \gamma_{\mathrm{t}}(\mathrm{SS})$, and $k_{\mathrm{des}}$ can be described in the form of the Arrhenius expression. Namely, $\ln \gamma_{\mathrm{t}}($ Ini $)=-16.58+$ $601.39 / T ; \ln \gamma_{\mathrm{t}}(\mathrm{SS})=-11.21-1325.04 / T ; \ln k_{\mathrm{des}}=-1.10-$ 758.50/T. A linear regression of these data yields an activation energy for $\mathrm{R} 1$ on $\mathrm{MgO}$ of $11.02 \pm 0.34 \mathrm{~kJ} \cdot \mathrm{mol}^{-1}$, and the activation energy for desorption is $6.30 \pm 0.81 \mathrm{~kJ} \cdot \mathrm{mol}^{-1}$. Usually, for a given reaction in the atmosphere, when the activation energy is greater than $20 \mathrm{~kJ} \cdot \mathrm{mol}^{-1}$, the role of this reaction in atmospheric chemistry is regarded as unimportant. ${ }^{15}$ It suggests that the heterogeneous reaction of COS on mineral oxides should not be neglected in the troposphere. The energy change in the reaction coordinate was shown in Figure 7, where the energy gap between the adsorbed intermediate $\left(\mathrm{HSCO}_{2}{ }^{-}\right)$

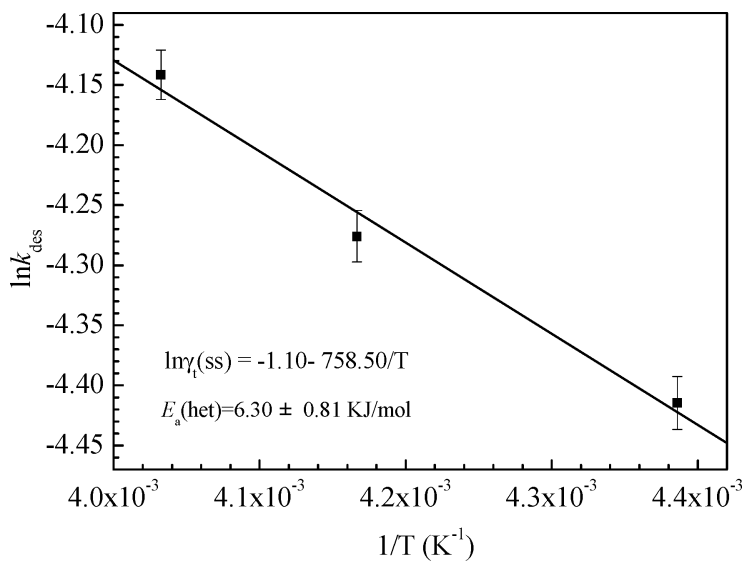

Figure 6. The relationship between desorption rate constants and temperature. 


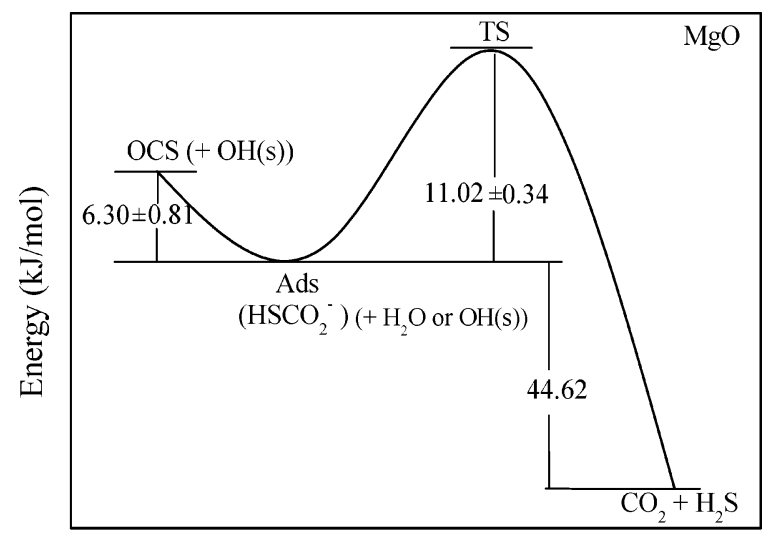

Reaction coordinate

Figure 7. The energy change in the reaction coordinate of COS on $\mathrm{MgO}$.

and the final products was calculated to be $44.62 \mathrm{~kJ} \cdot \mathrm{mol}^{-1}$ using Gaussian 98 (DFT-6-31G-B3LYP). As discussed above, the reverse reaction is less likely than the positive reaction. Therefore, the activation energy for the reaction between $\mathrm{CO}_{2}$ and $\mathrm{H}_{2} \mathrm{~S}$ should be higher than that for the inversed process. Therefore, the energy of $\mathrm{CO}_{2}$ and $\mathrm{H}_{2} \mathrm{~S}$ was given below that of the adsorbed species. Figure 7 shows that, when COS is adsorbed on $\mathrm{MgO}$, the heterogeneous reaction is more sensitive to temperature than the desorption process, and the heterogeneous reaction of $\mathrm{COS}$ on $\mathrm{MgO}$ is in favor of a high temperature.

\section{Conclusions and Atmospheric Implications}

In this work, the uptake of $\mathrm{COS}$ on $\mathrm{MgO}$ has been investigated at a temperature scope from 228 to $300 \mathrm{~K}$. The initial adsorption rate constants increase with the decreasing of temperature, while the desorption rate constants and the heterogeneous reaction rate constants increase with the enhancement of temperature. The empirical formula between the uptake coefficients and desorption rate constants and temperature can be described in the form of the Arrhenius equation. That is, $\ln$ $\gamma_{\mathrm{t}}$ (Ini) $=-16.58+601.39 / T ; \ln \gamma_{\mathrm{t}}(\mathrm{SS})=-11.21-1325.04 /$ $T ; \ln k_{\mathrm{des}}=-1.10-758.50 / T$. The activation energy for the heterogeneous reaction and desorption of COS on $\mathrm{MgO}$ were measured to be $11.02 \pm 0.34 \mathrm{~kJ} \cdot \mathrm{mol}^{-1}$ and $6.30 \pm 0.81$ $\mathrm{kJ} \cdot \mathrm{mol}^{-1}$, respectively. The relatively low activation energy indicates that the heterogeneous reactions of COS on mineral dust particles may have an important role in the sink of COS in the atmosphere. The empirical formula between the uptake coefficients and temperature can be used to predict the uptake coefficient at any temperature in the atmosphere.

As pointed out in the Introduction section, the temperature in the earth's atmosphere varies with altitude above the earth's surface. At high troposphere, COS can adsorb on the mineral dust particles quickly. The saturated adsorptive capacity for COS on $\mathrm{MgO}$ was measured to be $7.1 \pm 1.2 \times 10^{18}$ molecules $\cdot \mathrm{g}^{-1}$. Mineral dust particles smaller than $10 \mu \mathrm{m}$ can be transported over thousands of kilometers and are found far away from their sources. ${ }^{22,37}$ Therefore, the adsorbed COS can sink to the earth's surface or be transported to elsewhere with mineral dust particles. With the assumption of the global flux of 1000-3000 $\mathrm{Tg} \cdot \mathrm{yr}^{-1}$ for mineral dust in the troposphere, the fraction of $\mathrm{MgO}$ in the mineral dust particles of $6.1 \%,{ }^{19,38}$ and the saturated adsorptive capacity for $\mathrm{COS}$ on $\mathrm{MgO}$, the total sink flux of COS due to adsorbing on mineral dust and then sink with the mineral dust is estimated to be $0.04-0.13 \mathrm{Tg} \cdot \mathrm{yr}^{-1}$. As for low troposphere, especially in the boundary layer, the concentration of mineral particles is very high, and the atmospheric temperature may reach $330 \mathrm{~K}$. Therefore, the role of the catalytic reactions of COS on mineral particles in its sinks will become prominent. Our results also indicate that it should be cautious when the uptake coefficients for trace gases on mineral particles used in the model studies, especially obtained at one temperature point, and the temperature factor for the uptake coefficients should be considered.

Acknowledgment. This research was funded by National Natural Science Foundation of China (40775081, 50621804) and the Ministry of Science and Technology, China(2007CB407301).

\section{References and Notes}

(1) Turco, R. P.; Whitten, R. C.; Toon, O. B.; Pollack, J. B.; Hamill, P. Nature 1980, 283, 283-286. 9005

(2) Chin, M.; Davis, D. D. J. Geophys. Res. 1995, 100 (DS), 8993-

(3) Watts, S. F. Atmos. Environ. 2000, 34, 761-799.

(4) Kjellström, E. J. Atmos. Chem. 1998, 29, 151-177.

(5) Crutzen, P. J. Geophys. Res. Lett. 1976, 3, 73-76.

(6) Jacob, D. J. Atmos. Environ. 2000, 34, 2131-2159.

(7) Dentener, F. J.; Carmichael, G. R.; Zhang, Y.; Lelieveld, J.; Crutzen, P. J. J. Geophys. Res. 1996, 101, 22869-22889.

(8) Usher, C. R.; Michel, A. E.; Stec, D.; Grassian, V. H. Atmos. Environ. 2003, 37, 5337-5347.

(9) Wu, H. B.; Wang, X.; Cheng, J. M.; Yu, H. K.; Xue, H. X.; Pan, X. X.; Hou, F. Q. Chin. Sci. Bull. 2004, 49, 1231-1235.

(10) Wu, H. B.; Wang, X.; Cheng, J. M. Sci. China, Ser. B: Chem. 2005, 48, 31-37.

(11) He, H.; Liu, J. F.; Mu, Y. J.; Yu. Y. B.; Chen, M. X. Environ. Sci. Technol. 2005, 39, 9637-9642.

(12) Liu, J. F.; Yu, Y. B.; Mu, Y. J.; He, H. J. Phys. Chem. B 2006 $110,3225-3230$.

(13) Liu, Y. C.; He, H.; Xu, W. Q.; Yu, Y. B. J. Phys. Chem. A 2007, $111,4333-4339$.

(14) Liu, Y. C.; Liu, J. F.; He, H.; Yu, Y. B.; Xue, L. Chin. Sci. Bull. 2007, 52, 2063-2071.

(15) Simth, I. W. M. Chem. Rev. 2003, 103, 4549-4564.

(16) Toon, O. B.; Hamill, P.; Turzo, P. P.; Pinto, J. Geophys. Res. Lett. 1986, 13, 1284-1287.

(17) Tolbert, M. A.; Rossi, M. J.; Golden, D. M. Science 1988, 240, $1018-1021$.

(18) Finlayson-Pitt, B. J. Chem. Rev. 2003, 103, 4801-4822.

(19) Usher, C. R.; Michel, A. E.; Grassian, V. H. Chem. Rev. 2003, $103,4883-4939$.

(20) Ammann, M.; Kalberer, M.; Jost, D. T.; Tobler, L.; Rössler, E.; Plguet, D.; Gäggeler, H. W.; Baltensperger, U. Nature 1998, 395, 157160.

(21) Grassian, V. H. J. Phys. Chem. A 2002, 106, 860-877.

(22) Seisel, S.; Pashkova, A.; Lian, Y.; Zellner, R. Faraday Discuss. 2005, 130, 437-451.

(23) Tabazadeh, A.; Jacobon, M. Z.; Singh, H. B.; Toon, O. B.; Lin, J. S.; Chatfield, R. B.; Thakur, A. N.; Talbot, R. W.; Dibb, J. E. Geophys. Res. Lett. 1998, 25, 4185-4188.

(24) Zhang, Z. Q.; Friedlander, S. Environ. Sci. Technol. 2000, 34, 4687-4694

(25) Li, P.; Al-Abadleh, H. A.; Grassian, V. H. J. Phys. Chem. A 2002, $106,1210-1219$.

(26) Underwood, G. M.; Li, P.; Usher, C. R.; Grassian, V. H. J. Phys. Chem. A 2000, 104, 819-829.

(27) Beichert, P.; Finlayson-Pitts, B. J. J. Phys. Chem. 1996, 100, $15218-15228$.

(28) Tabor, K.; Gutzwiller, L.; Rossi, M. J. J. Phys. Chem. A 1994, 98 , $6172-6186$.

(29) Ullerstam, M.; Johnson, M. S.; Vogt, R.; Ljungström, E. Atmos Chem. Phys. 2003, 3, 2043-2051.

(30) Al-Abadleh, H. A.; Grassian, V. H. J. Phys. Chem. A 2000, 104, 11926-11933.

(31) Frinak, E. K.; Wermeille, S. J.; Mashburn, C. D.; Tolbert, M. A Pursell, C. J. J. Phys. Chem. A 2004, 108, 1560-1566.

(32) Gebel, M. E.; Finlayson-Pitts, B. J. J. Phys. Chem. A 2001, 105 , $5178-5187$

(33) Underwood, G. M.; Li, P.; Al-Abadleh, H. A.; Grassian, V. H. J. Phys. Chem. A 2001, 105, 6609-6620.

(34) Carlos-Cuellar, S.; Li, P.; Christensen, A. P.; Krueger, B. J.; Burrichter, C.; Grassian, V. H. J. Phys. Chem. A 2003, 107, 42504261. 
(35) Ravishankara, A. R. Science 1997, 276, 1058-1065.

(36) Seisel, S.; Lian, Y.; Keil, T.; Trukhin, M. E.; Zellner, R. Phys. Chem. Chem. Phys. 2004, 6, 1926-1932.

(37) Husar, R. B.; Tratt, D. M.; Schichtel, B. A.; Falke, S. R.; Li, F.; Jaffe, D.; Gassó, S.; Gill, T.; Laulainen, N. S.; Lu, F.; Reheis, M. C.; Chun, Y.; Westphal, D.; Holben, B. N.; Gueymard, C.; McKendry, I.; Kuring,
N.; Feldman, G. C.; McClain, C.; Frouin, R. J.; Merrill, J.; Dubois, D.; Vignola, F.; Murayama, T.; Nickovic, S.; Wilson, W. E.; Sassen, K.; Sugimoto, N.; Malm, W. C. J. Geophys. Res. 2001, 106 (D16), 1831718330

(38) Usher, C. R.; Al-Hosney, H.; Carlos-Cuellar, S.; Grassian, V. H. J. Geophys. Res. 2002, 107, 4713-4721. 